\title{
Pengaruh Pelayanan Mobile Banking Terhadap Kepuasan Nasabah (Studi Pada Mahasiswa Perbankan Syariah IAIN Palu)
}

\author{
Nurdin Nurdin, ${ }^{1}$ Indah Musyawarah ${ }^{2 *}$ Nurfitriani Nurfitriani ${ }^{3}$, Abdul jalil ${ }^{4}$ \\ ${ }^{1}$ Jurusan Perbankan Syariah, Fkultas Ekonomi dan Bisnis Islam, IAIN Palu \\ ${ }^{2}$ Jurusan Perbankan Syariah, Fkultas Ekonomi dan Bisnis Islam, IAIN Palu \\ ${ }^{3}$ Jurusan Perbankan Syariah, Fkultas Ekonomi dan Bisnis Islam, IAIN Palu \\ ${ }^{4}$ Jurusan Perbankan Syariah, Fkultas Ekonomi dan Bisnis Islam, IAIN Palu
}

\begin{abstract}
ABSTRAK
Penelitian ini bertujuan untuk mengetahui apakah kecepatan secara partial berpengaruh signifikan terhadap kepuasan nasabah dan apakah keamanan secara partial berpengaruh signifikan terhadap kepuasan nasabah. Selanjutnya penelitian ini juga bertujuan untuk mengetahui apakah akurasi dan kepercayaan secara partial berpengaruh signifikan terhadap kepuasan nasabah. Jenis penelitian ini adalah penelitian verifikatif dengan menggunakan pendekatan kuantitatif. Sampel penelitian ini sebanyak 40 responden yang diambil dengan metode sensus. Teknik pengumpulan data menggunakan kuesioner dan survei. Metode analisis data menggunakan uji regresi linear berganda, uji asumsi klasik, uji hipotesis (uji T, uji F dan uji R), kemudian data diolah menggunakan aplikasi SPSS 21 for windows. Dari hasil uji t menunjukkan bahwa variable kecepatan memiliki nilai $\mathrm{T}_{\text {hitung }}<\mathrm{T}_{\text {tabel }}$ atau sebesar 1,338 $<$ 1,683 dan nilai signifikan sebesar, 190>0,05 maka dapat disimpulkan bahwa $\mathrm{H}_{1}$ ditolak, Variabel keamanan memiliki nilai $\mathrm{T}_{\text {hitung }}<\mathrm{T}_{\text {tabel }}$ atau sebesar -,472<1,683dan nilai signifikan sebesar ,640>0,05 maka dapat disimpulkan bahwa $\mathrm{H}_{2}$ ditolak, Variable akurasi data memiliki nilai $\mathrm{T}_{\text {hitung }}<\mathrm{T}_{\text {tabel }}$ atau sebesar, $990<1,683$ dan nilai signifikan sebesar ,329>0,05 maka dapat disimpulkan bahwa $\mathrm{H}_{3}$ ditolak, Variabel kepercayaan memiliki nilai $T_{\text {hitung }}>T_{\text {tabel }}$ atau sebesar 4,142 > 1,683 dan nilai signifikan sebesar $, 000<0,05$ maka dapat disimpulkan bahwa dan $\mathrm{H}_{4}$ diterima. Dan uji $\mathrm{R}^{2}$ 0.601, hal ini dapat diartikan bahwa Variabel independen (Kecepatan, Keamanan, akurasi data, dan Kepercayaan) dapat menjelaskan variabel dependen (Kepuasan nasabah) sebesar $601 \%$, sedangkan sisanya diterangkan oleh faktor lain yang tidak diteliti.
\end{abstract}

INFORMASI

ARTIKEL

Katakunci:

Mobile banking, pelayanan, kepuasan nasabah, mahasisw 


\section{Jurnal Ilmu Perbankan dan Keuangan Syariah Vol. 1 No. 2 Tahun 2020}

\section{PENDAHULUAN}

Dalam kehidupan sehari-hari manusia tidak terlepas dari kegiatan transaksi. Transaksi tersebut memerlukan alat bayar berupa uang dimana kedua belah pihak harus bertemu langsung untuk melakukan transaksi. Namun kenyataan yang ada saat ini berbeda dengan dahulu. Saat ini terdapat banyak layanan yang disediakan oleh Bank guna mempermudah nasabah melakukan transaksi. Dengan kecanggihan teknologi yang ada saat ini, semua jenis transaksi bisa dilakukan dengan menggunakan media elektronik tanpa melibatkan kontak fisik secara langsung.

Dalam dunia perbankan saat ini telah diramaikan dengan adanya fasilitas kemudahan bertransaksi secara mobile, hal tersebut terjadi seiring dengan tuntutan terhadap tersedianya kemudahan dan kesederhanaan prosedur yang semakin lama semakin meningkat. Masyarakat semakin menuntut kepraktisan dan mulai enggan menjalankan suatu prosedur yang tidak hanya menghabiskan banyak waktu namun tanpa terasa telah mengikis sumber pendapatan seseorang. Hal ini menjadi dasar pemikiran para nasabah untuk mulai beralih dari kebiasaannya selama ini.

Sebelumnya para nasabah sudah cukup puas dengan adanya transaksi menggunakan Anjungan Tunai Mandiri (ATM). Namun sekarang kepuasan tersebut cepat menghilang, karena bertransaksi dengan menggunakan ATM tidak jauh beda dengan datang langsung ke bank, bahkan terkadang nasabah harus tetap mengantri untuk menunggu gilirannya tiba. Dilain pihak, tingginya tingkat kriminalitas yang melahirkan kebutuhan masyarakat akan keamanan dan kepraktisan dalam melakukan segala transaksi. Industri perbankan tahu benar memanfaatkan hal itu. Fungsi utama bank sebagai tempat menabung dan sumber kredit pun dikembangkan. Saat ini, dalam bersaing satu sama lain, bank-bank tidak hanya mengandalkan dua fungsi utama tersebut, melainkan berlomba memberikan layanan yang sebanyak mungkin dapat dilibatkan langsung dalam melakukan transaksi sehari hari. ${ }^{1}$

Hal ini menyebabkan dunia perbankan mulai memutar otak dan menggagas formula untuk mengembangkan dan membuka jaringan untuk pelayanan kepada nasabah berupa layanan mobile banking. Bank telah memanfaatkan perkembangan teknologi informasi dalam layanan perbankannya dengan meluncurkan media layanan transaksi perbankan berbasis teknologi informasi yaitu mobile banking. ${ }^{2}$ Layanan mobile banking membuka kesempatan bagi nasabah untuk melakukan transaksi perbankan melalui perangkat handphone.

Mempertimbangkan fenomena telepon seluler sebagai alat komunikasi yang paling diminati saat ini, maka sangat besar peluang para nasabah yang

${ }^{1}$ Irwan, Indonesia Customer Statisfaction (Jakarta: PT. Elex Media Komputindo, 2004), h. 89.

2 Nurdin, N. (2016). The Roles of Information Technology in Islamic Bank Knowledge Management: A study of Two Syariah Banks in Palu. Hunafa: Jurnal Studia Islamika 13(2),

181-217. https://doi.org/https://doi.org/10.24239/jsi.v1 3i2.444.181-217 


\section{Jurnal Ilmu Perbankan dan Keuangan Syariah Vol. 1 No. 2 Tahun 2020}

akan menggunakan layanan mobile banking. Teknologi dan komunikasi memang sudah seharusnya digunakan untuk mempermudah penggunaannya. Mobile banking ini dapat diakses oleh nasabah selama 24 jam. Berbagai alasan nasabah membutuhkan mobile banking yaitu: praktis karena tidak perlu datang ke bank atau ATM, transaksi menjadi lebih cepat, mempermudah untuk cek saldo melalui handphone, mempermudah mencari informasi tentang produk bank, dan cara pengoprasiannya mudah.

Jika dilihat dari aktivitas financial yang dilakukan, layanan mobile banking lebih banyak digunakan untuk mencari informasi. Bahkan, jumlah aktivitas pencarian informasi bisa tiga kali lipat dibandingkan dengan kegiatan transaksi. Hal ini dikarenakan karakter masyarakat Indonesia yang masih belum percaya akantransaksi menggunakan mobile banking, selain itu juga kepercayaan nasabah terhadap resiko keamanan dalam menggunakan mobile banking masih kurang sehingga menimbulkan kekhawatiran akan terkena penipuan masih tinggi. Ini salah satu sebab pertumbuhan mobile banking cukup lambat.

Saat ini perilaku nasabah bank Indonesia tidak mudah untuk ditebak, ada nasabah yang menginginkan suku bunga yang rendah (contoh pinjaman) atau suku bunga yang tinggi (contoh tabungan, giro dan deposito), biaya administrasi yang rendah dan ada pula nasabah yang menginginkan transaksi keuangan yang cepat, efisien, nyaman dan mudah dalam bertransaksi, kapanpun dan dimanapun. ${ }^{3}$

Dunia perbankan dewasa ini telah menyadari bahwa nasabah saat ini tidak hanya mempertimbangkan bank apa saja tempat mereka menabung atau berinvestasi, tidak hanya mempertimbangkan bunga atau keuntungan yang akan didapatkan dalam perbankan tersebut, akan tetapi nasabah juga membutuhkan kecanggihan dan kelengkapan fitur dari suatu produk perbankan, karena saat ini yang dicari oleh nasabah tidak hanya value (nilai) yang akan didapatkan dari apa yang ditawarkan oleh pihak bank tersebut, melainkan kualitas dan kemudahan-kemudahan yang dapat membantu dan memperlancar transaksi nasabah tersbut. ${ }^{4}$

Banyak cara yang dapat dilakukan bank dalam memenuhi kebutuhan, keinginan dan kepuasan nasabah, salah satunya yaitu dengan memberikan kesan dan citra yang baik dalam hal produk maupun pelayanan kepada nasabah. Dengan pelayanan yang baik, diharapkan nasabah akan merasa dihargai dan tidak merasa diabaikan haknya dan akhirnya nasabah sbagai pengguna atau pelanggan dari jasa yang ditawarkan oleh bank tersebut akan merasa puas.

\footnotetext{
${ }^{3}$ Putro Ismed Hasan, Bank BRI Terbaik di Awal Millennium (Jakarta: Masyarakat Profesional Madani, 2004), h. 193).

4 Nurdin, N., \& Yusuf, K. (2020). Knowledge management lifecycle in Islamic bank: the case of syariah banks in Indonesia. International Journal of Knowledge Management Studies, 11(1), 59-80. https://doi.org/10.1504/ijkms.2020.105073
} 


\section{Jurnal Ilmu Perbankan dan Keuangan Syariah

Saat ini penggunaan teknologi telah berkembang dengan cepat tidak hanya dinegara-negara maju tapi juga pada negara-negara berkembang seperti Indonesia. Perkembangan teknologi yang kemudian memunculkan mobile bankingmerupakan alternative bisnis yang cukup menjanjikan, karena mobile banking dipandang memiliki banyak kemudahan bagi kedua belah pihak. Dengan adanya mobile bankingini jasa pelayanan bank kepada nasabah bisa ditingkatkan efisiensinya.

Mobile banking merupakan salah satu produk setiap bank yang mengandalkan kecanggihan teknologi GPRS (General Package Radio Service) untuk memudahkan nasabahnya dalam melakukan transaksi perbankan. Industri perbankan syariah yang merupakan industry jasa yang dari waktu sewaktu memperbaiki kualitas layanan. Karena karakteristik jasa terletak pada kecepatan, kemudahan pelayanan dan keamanan. Maka layanan kecepatan dan kemudahan pelayanan harus terus dikembangkan menggunakan bantuan teknologi. Sistem perbankan dalam ekonomi Islam (perbankan Syariah) didasarkan pada konsep pembagian baik keuntungan maupun kerugian karena semua oprasional dan produknya dikembangan berlandaskan pada AlQur'an dan al_Hadits nabi SAW. ${ }^{5}$

Bagi bank, sangat penting sekali untuk mengetahui sejauh mana persepsi nasabah terhadap layanan Mobile bankingdan apakah dengan adanya

5Fahrurrozi, Wawancara, Mataram, 26 April 2015 layanan ini akan mendatangkan keuntungan bagi nasabah. Karena hal terpenting bagi nasabah adalah kemudahan-kemudahan memperoleh informasi keuangan dan bertransaksi secara online, tanpa harus mengunjungi bank tempat mereka menjadi nasabah.

Penelitian ini menitikberatkan pada pengaruh layanan mobile banking dalam bertransaksi terhadap kepuasan nasabah tersebut. Berdasarkan penelitian terdahulu yang meneliti bank pada terbesar diIndonesia serta dikemukakan oleh Gumesson dan Lovelock bahwa ketidakpuasan nasabah dipengaruhi oleh layananspeed (kecepatan), security (kemanan), accuracy, dan trust (kepercayaan). ${ }^{6}$ Namun pada penelitian ini peneliti meneliti semua bank dan yang digunakan adalah: kecepatan, keamanan, keakurasian dan kepercayaan. Kepuasan nasabah atas layanan mobile banking meliputi: kepuasan atas kecepatan, kepuasan atas keamanan, kepuasan atas akurasi data dan kepuasan atas kepercayaan.

\section{TINJAUAN PUSTAKA}

\subsection{Teori Pelayanan Mobile Banking}

Layanan adalah kegiatan yang ditawarkan oleh organisasi atau perorangan kepada konsumen, yang bersifat tidak berwujud dan tidak dapat

\footnotetext{
${ }^{6}$ Aditia wardana, Pengaruh Kualitas Layanan Mobile Banking ( $M$ Banking) TerhadapKepuasan Nasabah Di Indonesia, DeReMa Jurnal Manajemen 2, vol. 10 (September 2015).
} 


\section{Jurnal Ilmu Perbankan dan Keuangan Syariah Vol. 1 No. 2 Tahun 2020}

dimiliki ${ }^{7}$ dalam interaksi langsung antara seseorang dengan orang layanan atau mesin secara fisik, dan menyediakan kepuasan pelanggan.

Pelayanan merupakan rasa yang menyenangkan yang diberikan kepada orang lain disertai keramahan dan kemudahan dalam memenuhi kebutuhan mereka. Pelayanan diberikan sebagai tindakan atau perbuatan seseorang atau organisasi untuk memberikan kepuasan kepada pelanggan atau nasabah. Tindakan tersebut dapat dilakukan melalui cara langsung melayani pelanggan. Artinya karyawan langsung berhadapan dengan pelanggan atau menetapkan sesuatu dimana pelanggan atau nasabah sudah tahu tempatnya atau pelayanan melalui telepon. Tindakan yang dilakukan guna memenuhi kebutuhan pelanggan akan suatu produk atau jasa yang mereka butuhkan. ${ }^{8}$

Menurut Kotler definisi pelayanan adalah setiap tindakan atau kegiatan yang dapat ditawarkan oleh suatu pihak lain, yang pada dasarnya tidak berwujud dan tidak menagkibatkan kepemilikan apapun.Pelayanan merupakan layanan prilaku produsen dalam rangka memenuhi kebutuhan dan keinginan konsumen demi tercapainya kepuasan pada konsumen itu sendiri. ${ }^{9}$

${ }^{7}$ Muhammad Nur Rianto Al Arif, DasardasarPemasaran Bank Syariah (Bandung:Alfabeta. 2010), hal. 211.

${ }^{8}$ Kasmir, Etika Costumer Service(Jakarta: PT. Raja Grafindo, 2005). h. 15.

${ }^{9}$ Philip kotler, Manajemen Pemasaran: Analisis, Perencanaan dan Implementasi danKontrol, Jilid I (Jakarta: Erlangga, 2001), h.83.
Menurut Kotler unsur pelayanan mobile banking yaitu terdiri dari kecepatan, keamanan, akurasi dan kepercayaan. ${ }^{10}$

a. Manfaat Kualitas Pelayanan

Kualitas pelayanan memberikan manfaat layanan sangat besar bagi pelanggan, karyawan maupun perusahaan. ${ }^{11}$

1) Manfaat bagi pelanggan

a) Pemenuhan kebutuhan.

b) Penghargaan mendapatkan layanan yang baik.

c) Kepercayaan sebagai mitra bisnis.

d) Kepercayaan terhadap perusahaan yang professional.

2) Manfaat bagi karyawan

a) Meningkatkan kepercayaan diri.

b) Menumbuhkan kepuasan pribadi.

c) Menumbuhkan semangat bekerja.

3) Manfaat bagi perusahaan

a) Peningkatan citra professional.

b) Kelangsungan usaha terjamin.

c) Meningkatkan laba perusahaan.

a. Pengertian Mobile Banking

Mobile banking adalah fasilitas layanan dalam pemberian kemudahan akses maupun kecepatan dalam memperoleh informasi terkini dan transaksi financial secara reel time. Mobile Banking dapat diakses oleh nasabah perorangan melalui ponsel yang memiliki teknologi GPRS. Produk layanan mobile banking adalah saluran distribusi bank untuk mengakses rekening yang dimiliki nasabah melalui

\section{${ }^{10}$ Ibid, h. 83.}

${ }^{11}$ Fandy Tjiptono \& Gregorius Chandra, Service, Quality \& Satisfaction Edisi 3, (Yogyakarta: Penerbit ANDI, 2011), h. 119. 


\section{Jurnal Ilmu Perbankan dan Keuangan Syariah Vol. 1 No. 2 Tahun 2020}

teknologi GPRS dengan sarana telepon seluler (ponsel). ${ }^{12}$

b. Manfaat Mobile Banking

Sebagai pemberi fasilitas layanan dalam kemudahan akses, berikut beberapa manfaa $\mathrm{t}$ dari Mobile Banking, yakni :13

1) Kenyamanan bertransaksi kapan saja dan dimana saja.

2) Kemudahan melakukan transaksi seperti layaknya di ATM.

3) Dapat diaplikasikan pada semua jenis SIM dan ponsel yang menggunakan teknologi GPRS.

4) Dilengkapi fitur special transfer real time kebank dan transfer kebukan pemegang rekening.

1. Teori Kepuasan Nasabah

a. Kepuasan

Kepuasan berasal dari bahasa latin yaitu satis yang berarti enough atau cukup, dan facere yang berarti to do atau melakukan. Jadi produk dan jasa yang bisa memuas-kan adalah yang sanggup memberikan sesuatu yang dicari konsumen sampai pada tingkat cukup. ${ }^{14}$

Kepuasan adalah perasaan senang atau kecewa seseorang yang muncul setelah membandingkan antara persepsi atau kesannya terhadap kinerja atau

\footnotetext{
${ }^{12}$ Aditya wardana, Pengaruh Kualitas Layanan Mobile Banking (M Banking) Terhadap Kepuasan Nasabah di Indonesia. DeReMa Jurnal Manajemen, No 2 Volume 10. September 2015.

${ }^{13}$ Fahrur Rozyi,Wawancara, Mataram, 26 April 2014.

${ }^{14}$ Hansel Jonathan, Analisis Pengaruh EServiceQuality Terhadap Customer Satisfaction yang berdampak pada Customer Loyality PT. bayu Buana travel Tbk. Journal the Winners, Volume 14 No. 2, h. 104-112.
}

hasil akan suatu barang dan harapanharapannya. ${ }^{15}$

b. Nasabah

Nasabah adalah orang atau badan hukum yang mempunyai rekening baik rekening atau pinjaman pada pihak bank. Sehingga nasabah merupakan orang yang biasa berhubungan dengan atau menjadi pelanggan bank. Dengan kata lain nasabah adalah pihak atau orang yang menggunakan dan secara sengaja menjadi langganan bank yang dipercayainya. ${ }^{16}$

c. Kepuasan Nasabah

Salah satu tujuan utama perusahaan jasa dalam hal ini adalah menciptakan kepuasan nasabah. Kepuasan nasabah sebagai hasil penilaian nasabah terhadap apa yang diharapkan dengan membeli dan mengkomsumsi suatu produk atau jasa. Kemudian harapan tersebut dibandingkan dengan kinerja yang diterimanya dengan mengkomsumsi produk atau jasa tersebut. ${ }^{17}$

Kepuasan pelanggan adalah "Thelevel of person's felt state from comparing a product's perceived performance in relation to the person's expectation". Dengan kata lain kepuasan pelanggan adalah tingkat perasaan seseorang setelah membandingkan

${ }^{15}$ Philip Kotler da Keller, Kevin Lane, Manajemen Pemasaran. (Edisi 13 Jilid 1 (Jakarta: 2009), h. 45.

${ }^{16}$ Muhammad Nur Rianto Al arif, Dasar-dasar Pemasaran Bank Syariah, h.189.

${ }^{17}$ Muhammad. Nur Rianto Al Arif, Dasardasar Pemasaran Bank Syariah,h. 192. 


\section{Jurnal Ilmu Perbankan dan Keuangan Syariah Vol. 1 No. 2 Tahun 2020}

kinerja atau hasil yang dirasakan dibandingkan dengan harapannya. ${ }^{18}$

Kepuasan mencerminkan penilaian seseorang tentang kinerja produk maupun jasa anggapnya, atau hasil dan kaitannya dengan ekspektasi. Kepuasan konsumen maupun nasabah akan tercapai jika presepsi fundamental konsumen atau nasabah terhadap kinerja produk maupun jasa sama dengan kinerja produk yang diharapkan. ${ }^{19}$

Salah satu kunci untuk mempertahankan pelanggan adalah dengan kepuasan pelanggan. Pelanggan yang sangat puas biasanya tetap setia dalam jangka waktu yang lama, membeli lagi ketika perusahaan memperkenalkanproduk baru dan memperbaharui produk lama, membicarakan hal-hal baik tentang perusahaan dan produknya kepada orang lain, tidak terlalu memperhatikan merek pesaing dan tidak terlalu sensitive terhadap harga, menawarkan ide produk atau jasa kepada perusahaan, dan biaya peanggan lebih mudah dibandingkan pelanggan baru karena transaksi dapat menjadi hal rutin. ${ }^{20}$

Beberapa studi menghubungkan tingkat kepuasan nasabah dengan prilaku nasabah, dimana akan terdapat beberapa tipe dari nasabah: ${ }^{21}$

18Philip Kotler, Marketing Management (U.S.A: Prentice Hall International, 1994), h. 40.

19Philip Kotler dan Keller Kevin L. Manajemen Pemasaran (Ed 12. Jilid 1. Jakarta PT Indeks , 2009), h. 14.

20Ibid., h. 140.

${ }^{21}$ Wulan Pinonotoan. Pengaruh E-Banking, Kualitas Pelayanan, Kualitas Komunikasi Dan Kepercayaan Terhadap Loyalitas Nasabah Pada PT. Bank Mandiri cabang manado. Jurnal Emba Vol. 1 No. 4, h. 192-201.
1) Nasabah yang puas atau apa yang didapatkan oleh nasabah tersebut melebihi apa yang diharpkannya, sehingga iya akan loyal terhadap produk tersebut dan akan terus melakukan pembelian kembali (repeated order).

2) Tipe nasabah defectors, yaitu nasabah yang merasa pelayanan yang diberikan oleh perusahaan tidak ada sesuatu yang lebih atau bersifat standar atau biasa saja, dan biasanya nasabah akan berhenti melakukan pembelin atas produk tersebut.

3) Tipe nasabah terrorist, yaitu nasabah yang mempunyai pengalaman buruk atau negative atas perusahaan, sehingga akan menyebarkan efek beranta yang negative kepada orang lain.

4) Tipe nasabah hostages,yaitu nasabah yang tidak puas akan suatu produk namun tidak dapat melakukan pembelian kepada barang lain, karena struktur pasar yang monopolistic atau harga yang murah. Meskipun nasabah tidak puas dengan pelayanan yang diberikan, namun karena tidak ada perusahaan lain senang atau tidak senang maka ia harus tetap menggunakannya.

5) Tipe nasabah mercenaries, yaitu nasabah yang sangat puas, namun tidak mempunyai kesetiaan terhadap produk tersebut.

d. Strategi Kepuasan Nasabah

Strategi untuk meningkatkan kepuasan pelanggan ada enam strategi untuk meningkatkan kepuasan pelanggan, diantaranya adalah: ${ }^{22}$

${ }^{22}$ Fandy Tjiptono, Strategi Pemasaran, Edisi 3 (Yogyakarta: ANDI, 2011), h. 57. 


\section{Jurnal Ilmu Perbankan dan Keuangan Syariah Vol. 1 No. 2 Tahun 2020}

1) Relationship

Strategy,menciptakan

Marketing jangka panjang untuk mewujudkan kesetiaan pelanggan melalui kemitraan.

2) Superior Cutomer Service Strategy, menawarkan jasa yang lebih baik dibandingkan jasa yang ditawarkan oleh pesaing.

3) Extra Ordinary Guarantees Strategy, memberikan jaminan istimewa untuk mengatasi kerugian pelanggan.

4) Customer Complai Handing Strategy, mengenai keluhan pelanggan untuk mengubah ketidak puasan dan loyalitas.

5) Service Performance Improvement Strategy, memperbaiki setiap dimensi kualitas jasa secara priodik dan terus menerus untuk meningkatkan kepuasan dan loyalitas pelanggan.

6) Quality Function Development Strategy, merancang strategi pengembangan fungsi kualitas untuk memenuhi kebutuhan dan tuntutan pelanggan.

\subsection{Pengertian kecepatan, keamanan,} akurasi dan kepercayaan mobile banking

Konsumen atau nasabah desawa ini memiliki kebutuhan/tuntutan yang lebih kompleks pada penyedia jasa layanan perbankan secara mobile. Salah satu aspek yang harus dipenuhi adalah kecepatan koneksi dalam sistem perbankan secara mobile. ${ }^{23}$

1. Keamanan mobile banking

Keamanan dalam sistem transaksi keuangan melalui sistem online

23Riganaldhy, Geerry. Analisis Faktorfaktor yang Mempengaruhi Trust Pengguna Mobile Banking di Indonesia, Skripsi Sarjana Strata I, tidak diterbitkan, (Yogyakarta: Fakultas ekonomi UII. 2009). merupakan faktor utama yang menjadi prioritas bagi nasabah untuk menggunakan jasa layananan mobile banking. Nasabah menuntut kepada pihak penyedia jasa layanan mobilebanking untuk dapat memberikan atau menjamin keamanan transaksi keuangan melalui media mobile banking ${ }^{24}$.

2. Akurasi data mobile banking

Seluruh jajaran bank harus menyajikan data dan informasi mobile banking secara akurat yang dapat dipertanggungjawabkan. ${ }^{25}$

3. Kepercayaan mobile banking

$$
\text { Kepercayaan adalah suatu }
$$
keyakinan dari pihak tertentu terhadap pihak lain dalam hubungan antara kedua belah pihak berdasarkan keyakinaan bahwa pihak yang dipercayainya akan memenuhi segala kewajiban sesuai yang diharapkan. ${ }^{26}$

\section{METODE PENELITIAN}

Pendekatan yang digunakan dalam penelitian ini adalah pendekatan kuantitaif, karena penelitian ini terfokus untuk mengetahui pengaruh layanan mobile banking kepuasan nasabah dalam menggunakan layanan bank. Penelitian ini dilakukan di Institut

${ }^{24}$ Herna, Kemala. Pengujian Tingkat Keamanan dan Privasi Pengaruhnya terhadap Keinginan untuk Menggunakan Mobile Banking.Skripsi Sarjana StrataI, tidak diterbitkan, (Yogyakarta: Fakultas Ekonomi UII. 2009).

${ }^{25}$ https://www.coursehero.com/file/p6v3 8ts/5-Integritas-dan-Akurasi-Data-Bank-aSeluruh-Jajaran-Bank-Harus-menyajikan-data/ 26Dwi Mastia Harlan, "Pengaruh Kemudahan Penggunaan, Kepercayaan, dan Resiko Terhadap Minat Transaksi menggunakan E-Banking (Skripsi, Akuntansi, Yogyakarta, 2014), h. 43. 


\section{Jurnal Ilmu Perbankan dan Keuangan Syariah

Agama Islam Negeri (IAIN) Palu yang terletak di Jl. Diponegoro No. 23 Palu. Adapun objek penelitian yaknicustomer satifaction Mahasiswa Institut Agama Islam Negeri Palu (IAIN). Lokasi penelitian dianggap representif terhadap judul yang diangkat peneliti, karena di samping objek yang dianggap tepat, juga memberikan nuansa baru peneliti dalam menambah pengalaman penelitian.

Peneliti memberikan questioner kepada 40 respondent mahaiswa jurusan perbankan syariah. Quesioner menggunakan lima skala likert .

Teknik analisis data yang digunakan dalam penelitian ini adalah analisis kuantitaif, yaitu proses analisis terhadap data-data yang berbentuk angka dengan cara perhitungan secara statistik untuk mengukur kualitas produk dan desain terhadap keputusan pembelian produk gadai emas. Analisa data dilakukan melalui tahap uni validitas, reabilitas, uji regresi berganda, dan uji asumsi klasik. Untuk oembuktian hipotesis penulis menggunakan uji f dan uji t. ${ }^{27}$

\section{HASIL DAN PEMBAHASAN}

\subsection{Deskripsi Umum Subjek Penelitian}

\subsection{Deskripsi Kuesioner dan Sampel Penelitian}

${ }^{27}$ Nurdin, N., \& Mir'atun, M. a. (2018). Do Government And Private Sharia Commercial Banks Practice Similar Financial Social Responsibility Disclosure. Hunafa: Jurnal Studia Islamika, 15(2), 285-321.
Penelitian ini dilakukan pada Mahasiswa IAIN Palu yang beralamatkan di Institut Agama Islam Negeri (IAIN) Palu, di Jl. Diponegoro No. 23 Palu. Data penelitian menggunakan instrumen kuesioner yang dibagikan kepada Mahasiswa Fakultas FEBI sebagai sampel penelitian. Kuesioner disebarkan oleh peneliti kepada sampel yang diteliti dengan perincian sebagai berikut:

Tabel 1 Deskripsi Kuesioner

\begin{tabular}{|c|c|c|c|c|}
\hline Jumlah Sampel & $\begin{array}{c}\text { Kuesioner } \\
\text { Disebar }\end{array}$ & $\begin{array}{c}\text { Kuesioner } \\
\text { Kemball }\end{array}$ & $\begin{array}{c}\text { Kuesioner } \\
\text { Diolah }\end{array}$ & Presentase \\
\hline 40 & 40 & 40 & 40 & $100 \%$ \\
\hline
\end{tabular}

Sirmber: Hasi Penelition

Dalam tabel dijelaskan bahwa jumlah sampel yang digunakan dalam penelitian ini adalah 40 orang mahasiswa IAIN Palu. Data responden dalam penelitian ini dijelaskan dalam tabel sebagai berikut:

Tabel 2 Deskripsi Responden

\begin{tabular}{|c|c|c|c|c|c|}
\hline \multicolumn{6}{|c|}{ JENISKELAMIN } \\
\hline & & Frequency & Percent & $\begin{array}{l}\text { Valid } \\
\text { Percent }\end{array}$ & $\begin{array}{c}\text { Cumabative } \\
\text { Pereent }\end{array}$ \\
\hline \multirow{3}{*}{ Valid } & Laki-laki & 11 & 27.5 & 27,5 & 27,5 \\
\hline & Perempuan & 29 & 72.5 & 72.5 & 100,0 \\
\hline & Total & 40 & 100,0 & 1010 & \\
\hline
\end{tabular}

Pada tabel menunjukkan bahwa dari 40 orang jumlah sampel dalam penelitian ini yang berjenis kelamin lakilaki berjumlah 11 orang (27.5\%) dan yang berjenis kelamin perempuan 29 orang $(72.5 \%)$. Sehingga sampel dalam penelitian ini sebagian besar berjenis kelamin perempuan. 


\section{Jurnal Ilmu Perbankan dan Keuangan Syariah Vol. 1 No. 2 Tahun 2020}

\subsection{Uji Validitas dan Reliabilitas}

Menggunakan instrument yang valid dan reliabel dalam pengumpulan data, maka diharapkan hasil penelitian akan menjadi valid dan reliabel. Instrument yang dinyatakan valid dan reliabel adalah instrument yang valid, berarti alat ukur yang digunakan untuk mendapatkan data (mengukur) itu valid. Sedangkan instrumen yang reliabel berarti bila digunakan untuk mengukur berkali-kali akan menghasilkan data yang sama.

1. Uji Validitas

Uji Validitas data penelitian ditentukan oleh proses pengukuran yang akurat. Suatu instrumen pengukur dikatakan valid instrumen tersebut mengukur apa yang seharusnya di ukur. Instrumen tersebut dapat mengukur konstrak sesusai yang yang diharapkan peneliti. Pendekatan yang dilakukan dalam penelitian ini adalah validitas konstrak (susunan), yang ditetapkan menurut analisis rasional terhadap isi test atau angket yang penilaiannya didasarkan pada pertimbangan subjektif individual dengan mempertimbangkan baik teori maupun instrumen pengukur itu sendiri. Menghitung korelasi antara masing-masing pertanyaan dengan skor total korelasi. Semua item pertanyaan yang mencapai batas minimal koefisien korelasi 0,30 dianggap memuaskan.

Tabel 3. Deskripsi Item

\begin{tabular}{|c|c|c|c|c|}
\hline \multicolumn{5}{|c|}{ Item-Total Statistics $X_{1}$} \\
\hline & $\begin{array}{l}\text { Scaie Mean if } \\
\text { Item Deleted }\end{array}$ & $\begin{array}{l}\text { Scale Variance } \\
\text { if Item Deleted }\end{array}$ & $\begin{array}{l}\text { Corrected } \\
\text { Item-Total } \\
\text { Correlation }\end{array}$ & $\begin{array}{c}\text { Cronbach's } \\
\text { Alpha if Itemi } \\
\text { Deleted }\end{array}$ \\
\hline $\mathrm{X} 1.1$ & 29,1500 & 11,638 & 590 & 879 \\
\hline $\mathrm{X} 1.2$ & 29.1750 & 10,404 & .753 & .862 \\
\hline $\mathrm{X} 1.3$ & 29.2000 & 11,087 & .706 & .867 \\
\hline $\mathrm{X1.4}$ & 29,0750 & 11,353 & .630 & 875 \\
\hline $\mathrm{X} 1.5$ & 29,1000 & 11,990 & 596 & .878 \\
\hline X1.6 & 28,8500 & 11,310 & $\$ 34$ & 874 \\
\hline $\mathrm{X} 1.7$ & 28,8250 & 12,046 & 608 & 878 \\
\hline $\mathrm{X} 1.8$ & 29,3000 & 9,703 & .774 & 861 \\
\hline \multicolumn{5}{|c|}{ Sumber: Hasal Pouthian } \\
\hline \multicolumn{5}{|c|}{ Item-Total Statistics $\mathrm{X}_{3}$} \\
\hline & $\begin{array}{l}\text { Seale Mean if } \\
\text { Item Deleted }\end{array}$ & $\begin{array}{l}\text { Scale Yariance } \\
\text { if Item Deleted }\end{array}$ & $\begin{array}{l}\text { Corrected } \\
\text { Item-Total } \\
\text { Correlation }\end{array}$ & $\begin{array}{c}\text { Cronbach's } \\
\text { Alpha if Item } \\
\text { Deleted }\end{array}$ \\
\hline X2.1 & 36,0250 & 19.871 & 586 & 864 \\
\hline $\mathrm{X} 2.2$ & 36.1250 & 18,728 & .677 & 856 \\
\hline $\mathrm{X} 2.3$ & 35,9790 & 19.051 & .625 & 860 \\
\hline $\mathrm{X} 2.4$ & 36,1000 & 18.144 & 723 & 852 \\
\hline $\mathrm{X} 2.5$ & 36,1000 & 19,169 & 581 & 864 \\
\hline $\mathrm{X} 2.6$ & 36,1500 & 18,438 & .806 & 848 \\
\hline $\mathbf{X} 2.7$ & 36,0750 & 19,661 & 559 & 865 \\
\hline $\mathrm{X} 2.8$ & 36,5000 & 18,872 & 433 & 882 \\
\hline X2.9 & 36,4500 & 19.177 & 593 & 863 \\
\hline$\times 2.10$ & 36,7500 & 19.577 & .494 & 870 \\
\hline
\end{tabular}

\begin{tabular}{|c|c|c|c|c|}
\hline \multicolumn{5}{|c|}{ Item-Total Statistics L3 } \\
\hline & $\begin{array}{l}\text { Scale Mean if } \\
\text { Item Deleted }\end{array}$ & $\begin{array}{l}\text { Scale Variance ir } \\
\text { Item Deleted }\end{array}$ & $\begin{array}{c}\text { Corrected Item } \\
\text { Total } \\
\text { Correlation }\end{array}$ & $\begin{array}{c}\text { Cronback's } \\
\text { Alpha if Item } \\
\text { Deleted }\end{array}$ \\
\hline $\mathrm{X} 3.1$ & 32,7000 & 12,472 & 513 & 835 \\
\hline $\mathrm{X} 3.2$ & 32.6750 & 11,610 & .692 & .814 \\
\hline $\mathrm{X} 33$ & 32,70001 & 12.831 & 512 & 834 \\
\hline $\mathrm{X} 3 . \mathrm{A}$ & 32,7000 & 12.164 & .627 & 822 \\
\hline $\mathrm{X} 3.5$ & 32,6250 & 13,010 & 5000 & .835 \\
\hline $\mathrm{X} 3.6$ & 32.6250 & 12.458 & .568 & 829 \\
\hline $\mathrm{X} 3.7$ & 32,4250 & 13,328 & 367 & 849 \\
\hline $\mathrm{X} 3.8$ & 32,6500 & 12.182 & .681 & 817 \\
\hline $\mathrm{X} 3.9$ & 32,7000 & 11,703 & .608 & .824 \\
\hline
\end{tabular}

\begin{tabular}{|c|c|c|c|c|}
\hline \multicolumn{5}{|c|}{ Iten-Total Statistics $\mathrm{X}_{4}$} \\
\hline & $\begin{array}{l}\text { Scale Seas if } \\
\text { Item Deleted }\end{array}$ & $\begin{array}{l}\text { Scale Variance } \\
\text { if Item Delefed }\end{array}$ & $\begin{array}{c}\text { Corrected Item- } \\
\text { Tetal } \\
\text { Correlation }\end{array}$ & $\begin{array}{c}\text { Cronbach's } \\
\text { Alpha if Iten } \\
\text { Deleted }\end{array}$ \\
\hline $\mathrm{X} 4.1$ & 29,0750 & 9,763 & .406 & $\$ 36$ \\
\hline $\mathrm{X} 4.2$ & 28,5750 & 10,251 & .466 & 819 \\
\hline $\mathbf{X} 4.3$ & 28,6750 & 9.815 & 611 & 801 \\
\hline $\mathrm{X} 4.4$ & 28,5000 & 10,410 & .527 & 812 \\
\hline $\mathrm{X} 4.5$ & 28.5000 & 9.231 & 576 & 806 \\
\hline $\mathrm{X} 4.6$ & 28.7750 & 8,999 & 685 & 788 \\
\hline $\mathrm{X} 4.7$ & 28.5750 & 10,046 &, 633 & 800 \\
\hline $\mathrm{X} 4,8$ & 28,5750 & 10,251 & 639 & 802 \\
\hline
\end{tabular}




\section{Jurnal Ilmu Perbankan dan Keuangan Syariah Vol. 1 No. 2 Tahun 2020}

\begin{tabular}{|c|c|c|c|c|}
\hline \multicolumn{5}{|c|}{ Item-Total Statistiks Y } \\
\hline & $\begin{array}{l}\text { Scale Mlean if } \\
\text { Item Deleted }\end{array}$ & $\begin{array}{l}\text { Scale Variance } \\
\text { if Ltem Deleted }\end{array}$ & $\begin{array}{c}\text { Corrected ltets- } \\
\text { Total } \\
\text { Correlation }\end{array}$ & $\begin{array}{l}\text { Cronbach's } \\
\text { Alpha if Item } \\
\text { Deleted }\end{array}$ \\
\hline Y.1 & 23,4000 & 10.656 & 361 & $\$ 48$ \\
\hline $\mathrm{Y} .2$ & 23,1250 & 10,830 & 409 & .841 \\
\hline Y.3 & 23,4000 & 8.759 & 559 & 828 \\
\hline Y.4 & 23,3000 & 9.036 &, 717 & .397 \\
\hline $\mathrm{Y} .5$ & 23,2250 & 9.102 & 660 & 806 \\
\hline Y.6 & 23,2500 & 9,372 & 661 & 807 \\
\hline Y.7 & 23,2000 & 8,472 & 804 & 781 \\
\hline
\end{tabular}

Berdasarkan tabel, Maka dapat dilihat bahwa seluruh pertanyaan untuk variabel kepuasan nasabah memiliki status valid, karena nilai rhitung pada kolom (Corrected Item Total Correlation) > rtabel sebesar 0,30

2. Uji Realibilitas

Uji realibilitas adalah alat untuk mengukur suatu kuesioer yang merupakan indikator dari variabel. Suatu kuesioner dinyatakan relibel atau handal jika jawaban seseorang terhadap pernyataan adalah konsisten atau stabil dari waktu ke waktu. Pengukuran realibitas menggunakan cara one shot atau pengukuran sekali saja yaitu:

Pengukuran hanya sekali saja dan kemudian hasilnya dibandingkan dengan pertanyaan lain atau mengukur korelasi antar jawaban pertanyaan. SPSS memberikan fasilitas untuk mengukur relibilitas dengan uji statistik cronbach alpha (a) suatu variabel dikatakan realibel jika memberikan nilai cronbach alpha> 0,60.3.

Tabel 4 Uji Reliabilitas

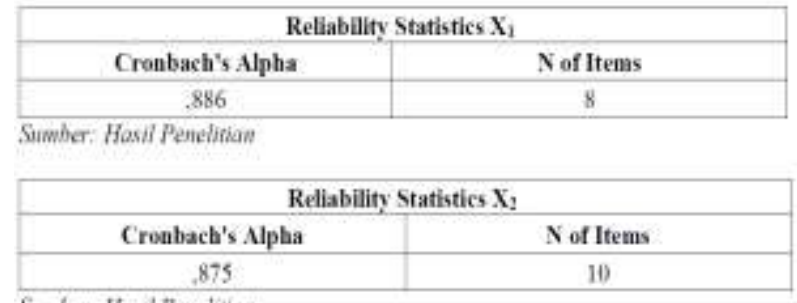

Simber: Hassl Penelinan

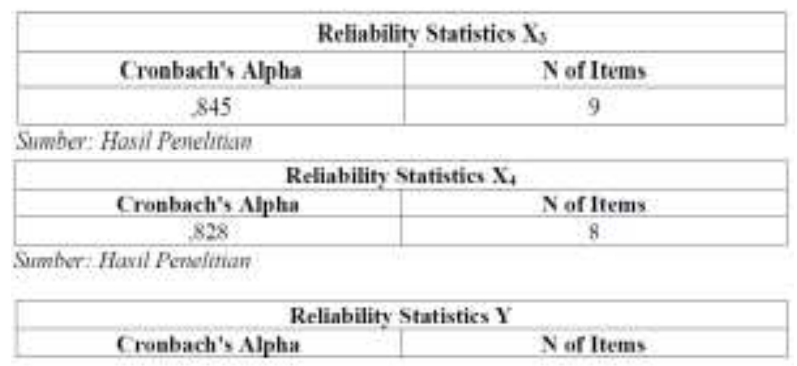

Tabel di atas dapat diketahui bahwa masing-masing variabel memiliki Cronbach's Alpha (a) lebih dari 0,60 (a $>0,60)$, yang artinya bahwa variabel $X$ dan $Y$ adalah reliabel. Dengan demikian pengolahan data dapat dilanjutkan ke jenjang selanjutnya.

\section{Deskripsi Variabel Penelitian}

Setelah data terkumpul, langkah selanjutnya adalah melakukan tabulasi data untuk melihat tanggapan responden mengenai variabel-variabel penelitian yaitu, Pelayanan mobile banking (variabel independen) dan Kepuasan nasabah (variabel dependen). Kemudian dicari rata-rata dari setiap jawaban responden, untuk memudahkan penilaian rata-rata tersebut, maka dibuat interval.

\subsection{Analisis Regresi Linear Berganda}

Berdasarkan hasil olah data menggunakan SPSS 21 for Windows diperoleh hasil analisis regresi berganda adalah sebagai berikut: 


\section{Jurnal Ilmu Perbankan dan Keuangan Syariah \\ Vol. 1 No. 2 Tahun 2020}

Tabel 5

Analisis Linear Berganda

\begin{tabular}{|c|c|c|c|c|c|c|}
\hline \multicolumn{7}{|c|}{ Coefficients" } \\
\hline & \multirow[t]{2}{*}{ Model } & \multicolumn{2}{|c|}{$\begin{array}{l}\text { Unstandardized } \\
\text { Coefficients }\end{array}$} & \multirow{2}{*}{$\begin{array}{c}\begin{array}{c}\text { Standanilizet } \\
\text { Coeflicients }\end{array} \\
\text { Beta } \\
\end{array}$} & \multirow[t]{2}{*}{ T } & \multirow[t]{2}{*}{ Sig. } \\
\hline & & B & Stu. Error & & & \\
\hline \multirow{5}{*}{1} & (Corstant) & 316 & 4,704 & &, 067 & .947 \\
\hline & $\begin{array}{c}\text { TOTAL. } \\
\text { KECEPATAN }\end{array}$ & .161 & .121 & .171 & 1,338 & .190 \\
\hline & TOTAL X2 &., 064 & 136 & .078 &., 472 & .640 \\
\hline & TOTAL X3 & .134 & .135 & .146 & .990 & 329 \\
\hline & TOTAL X4 & .699 & .169 &, 651 & 4,142 &, 000 \\
\hline & at Variable: I & AL. Y & & & & \\
\hline
\end{tabular}

Tabel ini bertujuan untuk mengetahui besarnya Pengaruh pelayanan Mobile banking terhadap kepuasan nasabah.

Harga $(X)$ diperoleh nilai Thitung 1,338< Ttabel 4,704 dan memiliki nilai signifikan (sig) 0.000 pada tabel coefficients dengan nilai a (tingkat signifikan) 0,05. Artinya $0.190>0,05$, dengan nilai ini memberikan makna bahwa variabel Kecepatan (X) tidak memberikan pengaruh secara signifikan terhadap Kepuasan nasabah (Y). Adapun besaran pengaruhnya dapat dilihat pada kolom Beta. Besaran pengaruh variabel $(X)$ terhadap variabel (Y) yaitu 0,171 atau 17,1\%.

Berdasarkan hasil perhitungan pada tabel, maka dapat dirumuskan persamaan regresi berganda sebagai berikut:

$\mathrm{Y}=0,316+0,171 \mathrm{X} 1-0,078 \times 2+0,146 \mathrm{X} 3$ $+0,651 \times 4+\mathrm{e}$

Dari persamaan regresi linear berganda tersebut dapat dijelaskan sebagai berikut:

1. Nilai 0,171 pada variabel kecepatan (X1) adalah bernilai positif sehingga dapat dikatakan bahwa semakin tinggi kecepatan mobile banking, maka akan semakin tinggi pula kepuasan nasabah.

2. 2 Nilai -,078 pada variabel keamanan (X2) adalah bernilai negatif sehingga dapat dikatakan bahwa semakin tinggi keamanan, tidak berarti akan semakin tinggi pula kepuasan nasabah.

3. 3 Nilai 0,146 pada variabel Akurasi data (X3) adalah bernilai positif sehingga dapat dikatakan bahwa semakin tinggi Akurasi data, maka akan semakin tinggi pula kepuasan nasabah.

4. 4 Nilai 0,651 pada variabel Kepercayaan (X4) adalah bernilai positif sehingga dapat dikatakan bahwa semakin tinggi Kepercayaan, maka akan semakin tinggi pula kepuasan nasabah.

\subsection{Uji Hipotesis}

a. Uji T (Parsial)

Tabel 7. Uji T Parsial

\begin{tabular}{|c|c|c|c|c|c|c|}
\hline \multicolumn{7}{|c|}{ Coefficients" } \\
\hline & \multirow[t]{2}{*}{ Model } & \multicolumn{2}{|c|}{$\begin{array}{l}\text { Tnstandardized } \\
\text { Coefficients }\end{array}$} & \multirow{2}{*}{ 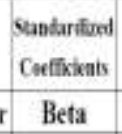 } & \multirow[t]{2}{*}{$\mathrm{T}$} & \multirow[t]{2}{*}{ Sig. } \\
\hline & & B & StL. Errer & & & \\
\hline \multirow{5}{*}{1} & (Coostant) &, 316 & 4,7144 & & .067 & 947 \\
\hline & $\begin{array}{c}\text { TOTAL } \\
\text { KECEPATAN }\end{array}$ &, 161 &, 121 & .171 & 1.338 & 190 \\
\hline & TOTAL X2 & .064 & .136 & .078 & -472 & 640 \\
\hline & TOTAL X3 & .134 & 135 & .146 & 990 & 329 \\
\hline & TOTAL X4 & 699 & .169 & .651 & 4,142 &, 000 \\
\hline a. 1 & dent Varable; T & AL Y & & & & \\
\hline
\end{tabular}

Digunakan untuk mengetahui pengaruh variable independen secara parsial (terpisah) terhadap variable dependen, apakah pengaruhnya signifikan atau tidak. Hipotesisakan diuji dengan taraf $\mathrm{a}=5 \%$. 


\section{Jurnal Ilmu Perbankan dan Keuangan Syariah Vol. 1 No. 2 Tahun 2020}

Jika Thitung > Ttabel, maka Ho ditolak dan Ha diterima. Jadi variable independen $(X)$ secara parsial memiliki pengaruh nyata terhadap dependen $(\mathrm{Y})$.

Jika Thitung < Ttabel, maka Ho diterima dan Ha ditolak. Jadi variable independen $(X)$ secara parsial memiliki pengaruh nyata terhadap dependen $(\mathrm{Y})$. a. Variabel Kecepatan

Berdasarkan hasil perhitungan diatas didapatkan nilai Thitung $<$ Ttabel atau sebesar 1,338 < 1,683 dan nilai signifikan sebesar ,190 >0,05maka dapat disimpulkan bahwa H0 diterima dan H1 ditolak yang artinya bahwa variabel kecepatan tidak berpengaruh signifikan terhadap kepuasan nasabah.

b. Variabel Keamanan

Berdasarkan hasil perhitungan diatas didapatkan nilai Thitung < Ttabel atau sebesar -,472< 1,683dan nilai signifikan sebesar ,640>0,05 maka dapat disimpulkan bahwa H0 diterima dan H2 ditolak yang artinya bahwa variabel keamanan tidak berpengaruh signifikan terhadap kepuasan nasabah. c. Variabel Akurasi Data

Berdasarkan hasil perhitungan diatas didapatkan nilai Thitung < Ttabel atau sebesar ,990<1,683 dan nilai signifikan sebesar ,329>0,05 maka dapat disimpulkan bahwa H0 diterima dan H3 ditolak yang artinya bahwa variabel akurasi data tidak berpengaruh signifikan terhadap kepuasan nasabah.

d. Variabel Kepercayaan

Berdasarkan hasil perhitungan diatas didapatkan nilai Thitung $>$ Ttabel atau sebesar 4,142 > 1,683 dan nilai signifikan sebesar ,000<0,05 maka dapat disimpulkan bahwa H0 ditolak dan H4 diterima yang artinya bahwa variabel kepercayaan berpengaruh signifikan terhadap kepuasan nasabah.

\section{b.Uji F (simultan)}

Digunakan untuk membuktikan kebenaran hipotesis dan mengetahui sejauh mana variable yang digunakan mampu menjelaskan variable terikan. Uji $F$ digunakan untuk menguji pengaruh variable bebas (independen) secara bersama terhadap variable terikat (dependen). Uji diilakukan dengan langkah membandingkan Fhitung dengan Ftabel.

Dasar pengambilan dalam uji ini ada 2 cara yaitu jika nilai signifikan < 0,05 maka H0 ditolak dan Ha diterima, artinya variable bebas secara bersamasama berpengaruh terhadap varaiabel terikat. Jika nilai signifikan $>0,05$ maka H0 diterima dan Ha ditolak, artinya variable bebas secara bersama-sama tidak berpengaruh terhadap variable terikat. Dan jika Fhitung < Ftabel, maka H0 diterima dan Ha ditolak. Dan jika nilai Fhitung > Ftabel maka H0 ditolak dan Ha diterima.

Tabel 8 Uji F

\begin{tabular}{|c|c|c|c|c|c|c|}
\hline \multicolumn{7}{|c|}{$\operatorname{ANOVA} A^{3}$} \\
\hline \multicolumn{2}{|c|}{ Model } & $\begin{array}{l}\text { Sum of } \\
\text { Squares }\end{array}$ & Df & $\begin{array}{l}\text { Slean } \\
\text { Square }\end{array}$ & $\mathrm{F}$ & Sig, \\
\hline \multirow{3}{*}{1} & Regression & 386,767 & 4 & 96,692 & 15,6194 &, $000^{1}$ \\
\hline & Residual & 215,633 & 35 & 6,161 & & \\
\hline & Toal & 602,400 & 39 & & & \\
\hline \multicolumn{7}{|c|}{ 2. Dependent Variable: TOTAL Y } \\
\hline \multicolumn{7}{|c|}{$\begin{array}{l}\text { b. Predictors: (Constant), TOTAL_X4, TOTAL X3, T0TAL KECEPATAN, } \\
\text { IOTAL X2 }\end{array}$} \\
\hline
\end{tabular}

Dari hasil uji $\mathrm{F}$ pada penelitian ini didapatkan nilai F hitung sebesar 15,694 dengan angka signifikan ( $\mathrm{P}$ value) sebesar 0,000 . Dengan tingkat signifikan $95 \%(\alpha=0,05)$. Angka signifikan ( $P$ value) sebesar $0,000<0,05$. Atas dasar perbandingan tersebut, maka $\mathrm{H} 0$ ditolak 


\section{Jurnal Ilmu Perbankan dan Keuangan Syariah Vol. 1 No. 2 Tahun 2020}

atau berarti variabel kecepatan, keamanan, akurasi data dan kepercayaan mempunyai pengaruh yang signifikan terhadap kepuasan nasabah.

\subsection{Pembahasan}

Penelitian ini bertujuan untuk mengetahui pengaruh kecepatan, keamanan, akurasi data dan kepercayaanterhadap kepuasan nasabah.

Hasil pengujian dengan menggunakan analisis regresi berganda dengan bantuan SPSS 21 for Windows:

\section{Pengaruh kecepatan mobile banking terhadap kepuasan nasabah}

Konsumen atau nasabah memiliki kebutuhan atau tuntutan yang lebih kompleks pada penyedia jasa layanan perbankan secara mobile. Salah satu aspek yang harus dipenuhi adalah kecepatan koneksi dalam system perbankan secara mobile. 6

Hasil uji secara parsial antara kecepatan mobile banking terhadap kepuasan nasabah menyatakan bahwa kecepatan mobile banking tidak berpengaruh positif terhadap kepuasan nasabah.

Hasil tersebut ditunjukkan dengan hasil uji parsial yaitu Thitung < Ttabel atau sebesar 1,338<1,683dan nilai signifikan sebesar $, 190>0,05$ maka dapat disimpulkan bahwa variabel kecepatan tidak berpengaruh signifikan terhadap kepuasan nasabah.

2. Pengaruh keamanan mobile banking terhadap kepuasan nasabah

Keamanan dalam system transaksi keuangan melalui system online merupakan factor utama yang menjadi prioritas bagi nasabah untuk menggunakan jasa layanan mobile banking. Nasabah menuntu kepada pihak penyedia jasa layanan mobile banking untuk dapat memberikan keamanan transaksi keuangan melalui media mobile banking.7

Hasil uji secara parsial antara kemudahan penggunaan dengan minat nasabah menggunakan layanan mobile banking menyatakan bahwa kemanan tidak berpengaruh positif terhadap kepuasan nasabah.

Hasil tersebut ditunjukkan dengan hasil uji parsial yaitu Thitung < Ttabel atau sebesar -,472 < 1,683 dan nilai signifikan sebesar ,640>0,05maka dapat disimpulkan bahwa variabel keamanan tidak berpengaruh signifikan terhadap kepuasan nasabah.

3. Pengaruh akurasi data mobile banking terhadap kepuasan nasabah

Seluruh jajaran bank harus menyajikan data dan informasi mobile banking secara akurat yang dapat dipertanggungjawabkan.8

Hasil uji secara parsial antara akurasi data mobile banking terhadap kepuasan nasabah menyatakan bahwa akurasi data mobile banking tidak berpengaruh positif terhadap kepuasan nasabah.

Hasil tersebut ditunjukkan dengan hasil uji parsial yaitu Thitung < Ttabel atau sebesar ,990<1,683 dan nilai signifikan sebesar ,329>0,05 maka dapat disimpulkan bahwa variabel akurasi data tidak berpengaruh signifikan terhadap kepuasan nasabah.

4. Pengaruh kepercayaan mobile banking terhadap kepuasan nasabah

Kepercayaan adalah suatu keyakinan dari pihak tertentu terhadap 


\section{Jurnal Ilmu Perbankan dan Keuangan Syariah Vol. 1 No. 2 Tahun 2020}

pihak lain dalam hubungan antara kedua belah pihak berdasarkian keyakinan bahwa pihak yang dipercayainya akan memenuhi segala kewajiban sesuai dengan yang diharapkan.9

Hasil uji secara parsial antara kepercayaan mobile banking terhadap kepuasan nasabah menyatakan bahwa kepercayaan mobile banking tidak berpengaruh positif terhadap kepuasan nasabah.

Hasil tersebut ditunjukkan dengan hasil uji parsial yaitu nilai Thitung $>$ Ttabel atau sebesar 4,142 $>1,683$ dan nilai signifikan sebesar ,000 < 0,05 maka dapat disimpulkan bahwavariabel kepercayaan berpengaruh signifikan terhadap kepuasan nasabah.

5. Pengaruh Variabel kecepatan (X1), keamanan (X2), akurasi data (X3), dan kepercayaan (X4) terhadap kepuasan nasabah $(Y)$.

Pengaruh kecepatan, keamanan, akurasi data, dan kepercayaan secara bersama-sama terhadap kepuasan nasabah berdasarkan pengujian perbandingan Fhitung > Ftabel yaitu sebesar 15,694 > 2,86 dan nilai signifikan $0,000<0,05$ hal ini dapat disimpulkan bahwa $\mathrm{H} 0$ ditolak dan $\mathrm{H} 4$ diterima yang berarti kecepatan, keamanan, akurasi data, dan kepercayaan secara bersamaan memiliki pengaruh simultan terhadap kepuasan nasabah.

\section{Kualitas pelayanan menurut perspektif Islam}

Menurut Thorik G. dan Utus H Pentingnya mmemberika pelayanan yang berkualitas disebabkan pelayanan (service) tidak hanya sekedar mengantarkan dan melayani. Servis berarti mengerti, memahami, dan merasakan sehingga penyampaiannya pun akan mengenai heartshare konsumen dan pada akhirnya memperkokoh posisi dalam mind share konsumen. Dengan adanya heartshare yang tertanam, loyalitas konsumen pada produk usaha perusahaan tidak diragukan.10

Dalam ibadah, hukum yang berlaku adalah bahwa seseorang dilarang, kecuali yang ada ketentuannya berdasarkan Al-qur'an dan hadits. Sedangkan dalam urusan muamalat, semua diperbolehkan kecuali ada dalil yang melarangnya. Ini berarti ketika suatu transaksi muncul dimana belum dikenal sebelumnya dalam hukun Islam, transaksi tersebut dapat diterima kecuali terdapat implikasi dari dalil al-quran dan al-hadits yang melarangnya secara implisit maupun ekspilisit. Jadi dalam bidang muamalat semua transaksi diperbolehkan kecuali yang diharamkan. Meskipun dalam kosa kata fiqh Islam tidak mengenal kata "Bank", namun sesungguhnya bukti-bukti sejarah menyatakan bahwa fungsifungsi perbankan modern telah dipraktekkan oleh umat islam, bahkan sejak zaman nabi Muhammad SAW.

Perusahaan perbankan khususnya perbankan syariah haruslah selalu memperhatikan kepentingan nasabahnya. Karena bank adalah lembaga yang bergerak dibidang pelayanan jasa keuangan. Walaupun begitu, setiap berhubungan dengan nasabah atau calon nasabah bank harus memperhatikan hukum-hukum islam yang berkaitan dengan akad. Adapun yang harus diperhatikan dalam 


\section{Jurnal Ilmu Perbankan dan Keuangan Syariah Vol. 1 No. 2 Tahun 2020}

memberikan layanan atau memasarkan produk yang sesuai dengan syariat islam adalah:

a. Setiap transaksi dalam islam harus didasarkan pada prindip kerelaan antara kedua belah pihak, jadi dalam memasarkan produk atau memberikan pelayanan tidak boleh ada unsur memaksa kepada nasabah atau calon nasabah. Setiap transaksi yang dilakukan nasabah berdasarkan kerelaan dari nasabah sendiri, termasuki saat nasabah melakukan transaksi menggunakan layanan mobile banking.

b. Setiap berhubungan dengan para nasabah atau calon nasabah harus menjelaskan tentang produk-produk secara detail tanpa menutup-nutupi hal sebenarnya.

c. Kejujuran komunikasi, aspek kejujuran komunikasi didasarkan pada data dan fakta. Dalam Al-quran kejujuran diistilakan dengan amanah, ghoir al takdzib, shiddiq, dan al-haq. Dengan dasar istilah-istilah tersebut, maka sesorang tidak akan berkomunikasi secara dusta.14

d. Berbuat adil yaitu dengan cara tidak melampaui batas atau mengambil menguntungkan yang tidak pantas dari kemalangan orang.

e. Kebersihan adalah dasar pokok dalam Islam, Islam dan kebersihan tidak dapat dipisahkan. Kebersihan meliputi segala sesuatu baik ucapan maupun perbuatan dan lain sebagainya.

\section{KESIMPULAN}

Dari hasil pengolahan data dan analisis data dalam penelitian dapat disimpulkan bahwa variabel kecepatan tidak berpengaruh signifikan terhadap kepuasan nasabah yang dibuktikan dengan nilai thitung 1,338 < nilai ttabel, 1,681 dan nilai signifikan sebesar 0,000 < 0,05 maka dapat disimpulkan bahwa H0 diterima dan $\mathrm{H} 1$ ditolak yang artinya bahwa variabel kecepatan tidak berpengaruh signifikan terhadap kepuasan nasabah.

Variabel keamanantidak berpengaruh signifikan terhadap kepuasan nasabah yang dibuktikan dengan nilai thitung -,472 < nilai ttabel,1,681 dan nilai signifikan sebesar $0,000<0,05$ maka dapat disimpulkan bahwa $\mathrm{H} 0$ diterima dan $\mathrm{H} 1$ ditolak yang artinya bahwa variabel keamanan tidak berpengaruh signifikan terhadap kepuasan nasabah.

Variabel akurasi datatidak berpengaruh signifikan terhadap kepuasan nasabah yang dibuktikan dengan nilai thitung ,990 < nilai ttabel, 1,681 dan nilai signifikan sebesar 0,000 < 0,05 maka dapat disimpulkan bahwa H0 diterima dan $\mathrm{H} 1$ ditolak yang artinya bahwa variabel akurasi data tidak berpengaruh signifikan terhadap kepuasan nasabah.

Variabel kepercayaan data tidak berpengaruh signifikan terhadap kepuasan nasabah yang dibuktikan dengan nilai thitung 4,142 > nilai ttabel, 1,681 dan nilai signifikan sebesar 0,000 < 0,05 maka dapat disimpulkan bahwa H0ditolak dan H1 diterima yang artinya bahwa variabel kepercayaan berpengaruh signifikan terhadap kepuasan nasabah. Hasil ini membuktikan bahwa semakin besar kepercayaan suatu teknologi maka 


\section{Jurnal Ilmu Perbankan dan Keuangan Syariah

semakin besar pula minat seseorang untuk menggunakannya.

Variabel kecepatan, keamanan, akurasi data, dan kepercayaan secara bersamasama terhadap kepuasan nasabah berdasarkan pengujian perbandingan Fhitung > Ftabel yaitu sebesar 15,694 > 2,64 dan nilai signifikan 0,000 < 0,05 hal ini dapat disimpulkan bahwa $\mathrm{H} 0$ ditolak danH4 diterima yang berarti kecepatan, keamanan, akurasi data, dan kepercayaan secara bersamaan memiliki pengaruh simultan terhadap kepuasan nasabah.

\section{Daftar Pustaka}

Aditia wardana, Pengaruh Kualitas Layanan Mobile Banking (M Banking) TerhadapKepuasan Nasabah Di Indonesia, DeReMa Jurnal Manajemen 2, vol. 10 (September 2015).

Dwi Mastia Harlan, "Pengaruh Kemudahan Penggunaan, Kepercayaan, dan Resiko Terhadap Minat Transaksi menggunakan E-Banking (Skripsi, Akuntansi, Yogyakarta, 2014), h. 43

Fahrurrozi, Wawancara, Mataram, 26 April 2015

Fandy Tjiptono \& Gregorius Chandra, Service, Quality $\mathcal{E}$ Satisfaction Edisi 3, (Yogyakarta: Penerbit ANDI, 2011), h. 119

Fahrur Rozyi,Wawancara, Mataram, 26 April 2014.

Fandy Tjiptono, Strategi Pemasaran, Edisi 3 (Yogyakarta: ANDI, 2011), h. 57

Hansel Jonathan, Analisis Pengaruh EServiceQuality

Terhadap
Customer Satisfaction yang berdampak pada Customer Loyality PT. bayu Buana travel Tbk. Journal the Winners, Volume 14 No. 2, h. 104-112.

Herna, Kemala. Pengujian Tingkat Keamanan dan Privasi Pengaruhnya terhadap Keinginan untuk Menggunakan Mobile Banking.Skripsi Sarjana StrataI, tidak diterbitkan, (Yogyakarta: Fakultas Ekonomi UII. 2009).

https://www.coursehero.com/file/p6v 38ts/5-Integritas-dan-Akurasi-

Data-Bank-a-Seluruh-Jajaran-

Bank-Harus-menyajikan-data/

Irwan, Indonesia Customer Statisfaction (Jakarta: PT. Elex Media Komputindo, 2004), h. 89

Kasmir, Etika Costumer Service(Jakarta: PT. Raja Grafindo, 2005). h. 15.

Muhammad Nur Rianto Al Arif, DasardasarPemasaran Bank Syariah (Bandung:Alfabeta. 2010), hal. 211.

Nurdin, N. (2016). The Roles of Information Technology in Islamic Bank Knowledge Management: A study of Two Syariah Banks in Palu. Hunafa: Jurnal Studia Islamika, 13(2), 181217.

https://doi.org/https:/ /doi.org/ 10.24239/jsi.v13i2.444.181-217

Nurdin, N., \& Mir'atun, M. a. (2018). Do Government And Private Sharia Commercial Banks Practice Similar Financial Social Responsibility Disclosure. Hunafa: Jurnal Studia Islamika, 15(2), 285-321. 


\section{Jurnal Ilmu Perbankan dan Keuangan Syariah \\ Vol. 1 No. 2 Tahun 2020}

Nurdin, N., \& Yusuf, K. (2020). Knowledge management lifecycle in Islamic bank: the case of syariah banks in Indonesia. International Journal of Knowledge Management Studies, 11(1), 59-80. https:// doi.org/10.1504/ijkms.20 20.105073

Philip kotler, Manajemen Pemasaran: Analisis,Perencanaan dan Implementasi danKontrol, Jilid I (Jakarta: Erlangga, 2001), h.83.

Philip Kotler, Marketing Management (U.S.A: Prentice Hall International, 1994), h. 40.

Philip Kotler da Keller, Kevin Lane, Manajemen Pemasaran. (Edisi 13 Jilid 1 (Jakarta: 2009), h. 45.

Putro Ismed Hasan, Bank BRI Terbaik di Awal Millennium (Jakarta:
Masyarakat Profesional Madani, 2004), h. 193).

Riganaldhy, Geerry. Analisis Faktorfaktor yang Mempengaruhi Trust Pengguna Mobile Banking di Indonesia, Skripsi Sarjana Strata I, tidak diterbitkan, (Yogyakarta: Fakultas ekonomi UII. 2009).

Wulan Pinonotoan. Pengaruh E-Banking, Kualitas Pelayanan, Kualitas Komunikasi Dan Kepercayaan Terhadap Loyalitas Nasabah Pada PT. Bank Mandiri cabang manado. Jurnal Emba Vol. 1 No. 4, h. 192-201. 